\title{
Refinement of the crystal structure of stibnite, $\mathrm{Sb}_{2} \mathrm{~S}_{3}{ }^{1}$ \\ By Peter Bayliss* and Werner Nowacki

\author{
Abteilung für Kristallographie und Strukturlehre, Universität Bern
}

(Received 20 September 1971)

\begin{abstract}
Auszug
Für Antimonit, $\mathrm{Sb}_{2} \mathrm{~S}_{3}$, wurde ein verfeinerter Satz von Atomkoordinaten und Temperaturparametern erhalten. Diese Struktur enthält parallele $\left(\mathrm{Sb}_{4} \mathrm{~S}_{6}\right)_{n}$ Ketten, welche miteinander verbunden sind und gewellte Netze bilden (zwei pro Einheitszelle). Das fünfwertige Sb weist eine Fünferkoordination in Form einer quadratischen Pyramide mit $\mathrm{Sb}$ leicht aus dem Basiszentrum verschoben auf. Das dreiwertige $\mathrm{Sb}$ hat eine Dreierkoordination in Form einer trigonalen Pyramide mit Sb als Spitze. Zwei dreiwertige S-Atome besitzen eine Dreierkoordination in Form einer trigonalen Pyramide mit $\mathrm{S}$ als Spitze. Das andere zweiwertige S-Atom hat eine Zweierkoordination. Die physikalischen Eigenschaften stehen mit der Kristallstruktur in Beziehung.
\end{abstract}

\section{Abstract}

A refined set of atomic coordinates and temperature parameters have been obtained for stibnite, $\mathrm{Sb}_{2} \mathrm{~S}_{3}$. This structure contains parallel $\left(\mathrm{Sb}_{4} \mathrm{~S}_{6}\right)_{n}$ chains, which are linked to form crumpled sheets (two per unit cell). The quinvalent $\mathrm{Sb}$ has fivefold coordination in a square pyramid, where tho $\mathrm{Sb}$ is slightly displaced out of the base center. The trivalent $\mathrm{Sb}$ has threefold coordination in a trigonal pyramid, where the $\mathrm{Sb}$ occupies the vertex. Two trivalent $\mathrm{S}$ have threefold coordination in a trigonal pyramid, where the $S$ occupies the vertex. The other divalent $\mathrm{S}$ has twofold coordination. The physical properties are related to the crystal structure.

\section{Introduction}

The crystal structure of stibnite $\left(\mathrm{Sb}_{2} \mathrm{~S}_{3}\right)$ was initially solved with a trial and error method by HoFmanN (1933). Later Ś́AvNIČAR (1960) redetermined the structure with a Fourier from two-dimensional Weissenberg-film data. The crystallochemical relations between $\mathrm{Sb}$ and

${ }^{1}$ Contribution No. 222, Part 64 on sulfides and sulfosalts.

* Present address : Department of Geology, University of Calgary, Alberta, Canada. 
$S$ appear in the stibnite structure without any interference from other elements. Therefore it is worthwhile to refine such an important structure in the sulfosalt-mineral class with three-dimensional counter data to obtain more accurate interatomic distances and bond angles, because of their deviation from the expected more ideal structure.

\section{Experimental}

Stibnite crystals donated by Mr. S. Liechti (Number 212, Mineralogisch-Petrographisches Institut, Universität Bern) were examined. Since the mineral is both too soft (hardness 2) and easily cleavable along perfect cleavage (100) to grind a cylinder without crystal distorsion, a needle with dimensions $23 \times 296 \times 29 \mu \mathrm{m}$ was used to measure the lattice constants and intensities.

The lattice constants were determined from two back-reflection Weissenberg photographs of $h 0 l$ and $0 k l$, which were calibrated for film shrinkage by the diffraction pattern of silicon $(a=5.43054 \AA)$. A least-squares best fit of the lattice constants was calculated by the program written by N. D. Jones (unpublished). The results are

\begin{tabular}{c|c|c|c}
\hline & Present study & Ś́́avničar (1960) & HoFMANN (1933) \\
\hline$a$ & $11.3107(9) \AA$ & $11.33(2) \AA$ & $11.28 \mathrm{kX}$ \\
$b$ & $3.8363(4)$ & $3.84(1)$ & 3.83 \\
$c$ & $11.2285(5)$ & $11.25(2)$ & 11.20
\end{tabular}

The observed density given by Dana (1941) is $4.63(2) \mathrm{g} \mathrm{cm}^{-3}$, and that calculated for $4 \mathrm{Sb}_{2} \mathrm{~S}_{3}$ on the basis of the new lattice constants is $4.62 \mathrm{~g} \mathrm{~cm}^{-3}$. The space group Pnma was chosen as assigned by both Ś́AVNiČAR (1960) and HoFMANN (1933) after reorientation to the standard setting with systematic absences of $0 k l$ with $k+l=2 n+1$ and $h k 0$ with $h=2 n+1$. Three-dimensional data was collected by a Weissenberg counter autodiffractometer (Supper-Pace type) with $\mathrm{Cu} K \propto$ radiation $(1.54178 \AA$ ). The intensities were corrected for both background and Lorentz and polarization factors. Corrections for absorption were calculated by a local version of the ACAC program written by Wuensch and Prewitt (1965), because the linear absorption coefficient is high $\left(\mu=1011 \mathrm{~cm}^{-1}\right.$ for $\left.\mathrm{Cu} K \alpha\right)$.

The structure was refined from the coordinates of Ś́AVNIČAR (1960) with a local version of the block-diagonal least-squares program 
Table 1. Observed and calculated structure factors for stibnite

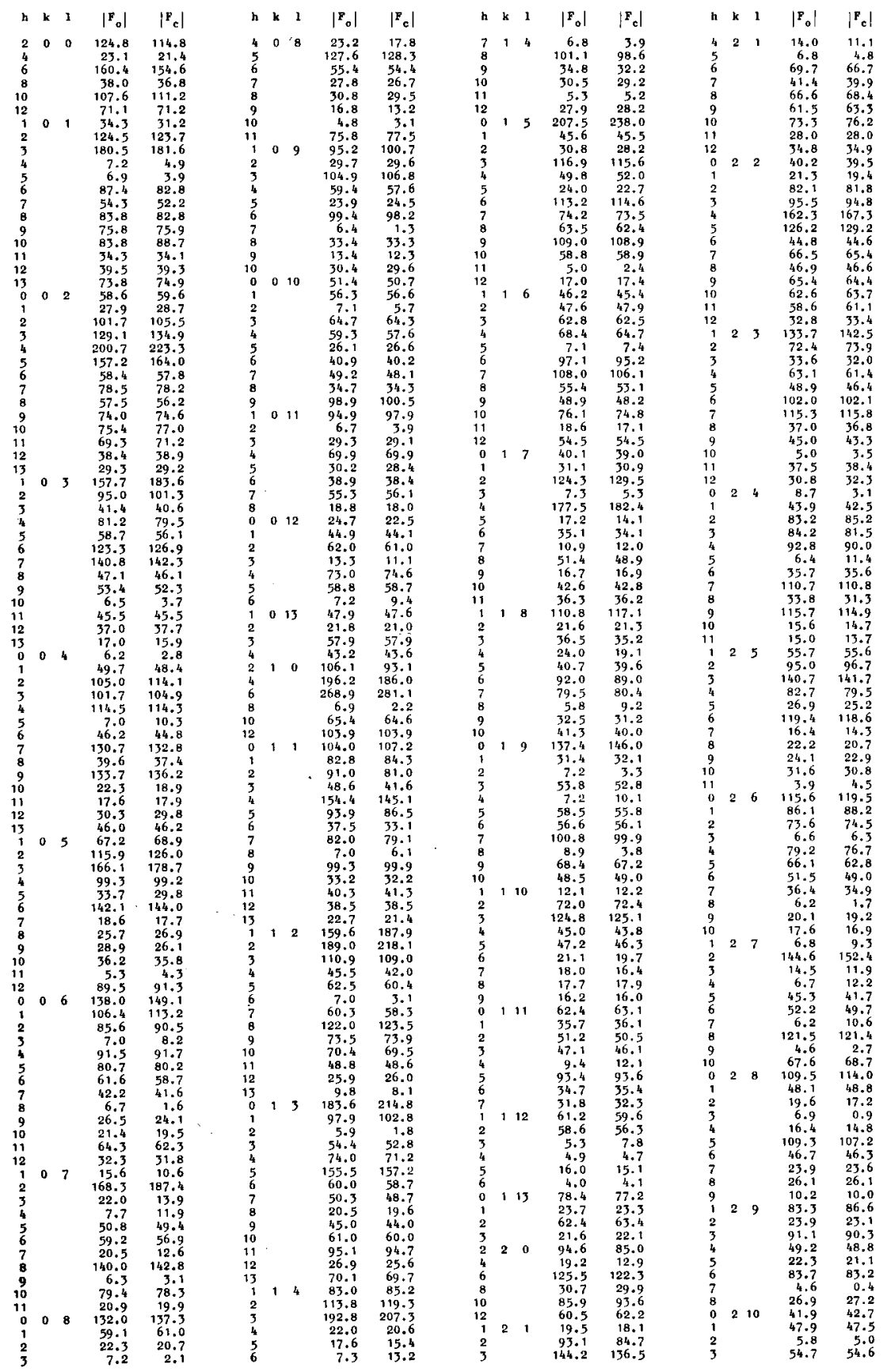




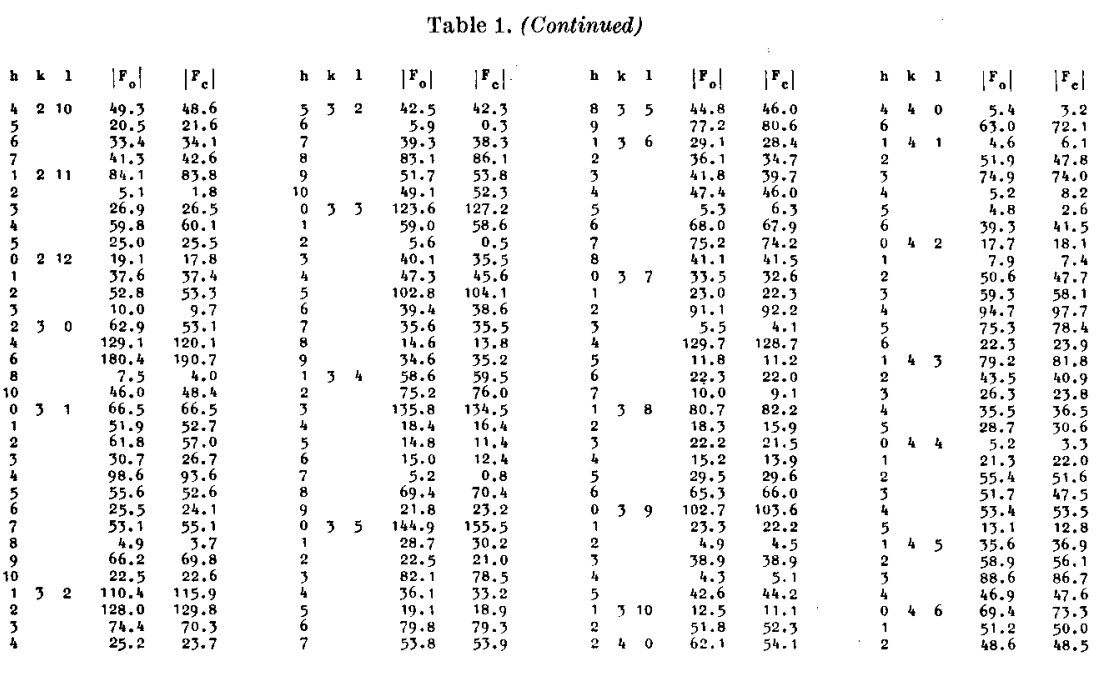

written by D. VAN DER HELM. The neutral-atom form scattering factors corrected for the real dispersion correction for $\mathrm{S}$ and $\mathrm{Sb}$ were taken from the International tables (1962). The final discrepancy index $R$ is 0.044 for all 532 reflections. Both observed and calculated structure amplitudes are shown in Table 1. No secondary-extinction correction has been made, although it has had an effect as shown by the results in Table 1.

\section{Diseussion of the structure}

The atomic coordinates and temperature parameters, which are given in Table 2, are similar to both HoFmann (1933) and Ś́avniǒar (1960). The interatomic distances and bond angles are tabulated in Table 3. A projection of the structure on the (010) plane is shown in Fig. 1.

The structure is formed of infinite $\mathrm{Sb}_{4} \mathrm{~S}_{6}$ chains parallel to the $b$ axis (needle axis) with interatomic distances between 2.455 and $2.854 \AA$. These chains are linked to form crumpled sheets perpendicular to the $a$ axis with interatomic distances of $3.167 \AA$. These sheets (two per unit cell) are held together with interatomic distances between 3.373 and $3.642 \AA$, whereas the sum of van der Waals radii for $\mathrm{Sb}$ and $\mathrm{S}$ is $4.05 \AA$. The $\mathrm{Sb}$ to $\mathrm{S}$ bonds are mainly covalent.

Each trivalent $\mathrm{Sb}_{\mathrm{I}}$ at the vertex of a trigonal pyramid is bonded to three $\mathrm{S}$ atoms (two divalent and one trivalent), which occupy the corners of the basal plane. This trigonal pyramid is slightly distorted as shown by the interatomic distances of SIII at $2.521 \AA$ and two SII $_{\text {II }}$ 
at $2.539 \AA$, and also the bond angles $\mathrm{S}_{\mathrm{II}}-\mathrm{Sb}_{\mathrm{I}}-\mathrm{S}_{\mathrm{III}}$ of $87.49^{\circ}$ and $\mathrm{S}_{\mathrm{II}}-$ $\mathrm{Sb}_{I}-\mathrm{S}_{\text {II }}$ of $98.13^{\circ}$. In addition another four $\mathrm{S}$ atoms (two $\mathrm{S}_{\mathrm{I}}$ at $3.111 \AA$, $\mathrm{S}_{I I}$ at $3.167 \AA$ and $\mathrm{S}_{\mathrm{III}}$ at $3.642 \AA$ ) lie near $\mathrm{Sb}_{\mathrm{I}}$. Each quinvalent $\mathrm{Sb}$ II, which lies just below the center $(0.17 \AA)$ of the basal plane of a distorted square pyramid, is bonded to five trivalent $S$ atoms, which occupy the corners of the square pyramid. This square pyramid is distorted as

Table 2. Atomic coordinates and temperature parameters of stibnite

\begin{tabular}{|c|c|c|c|c|c|}
\hline & & $\begin{array}{c}\text { HofmanN } \\
(1933)\end{array}$ & $\begin{array}{c}\text { Š́́AVNIČAR } \\
(1960)\end{array}$ & $\begin{array}{l}\text { Present } \\
\text { study }\end{array}$ & \\
\hline $\mathrm{Sb}_{\mathrm{I}}$ & $\begin{array}{l}x \\
y \\
z\end{array}$ & $\begin{array}{c}0.031 \\
1 / 4 \\
0.328\end{array}$ & $\begin{array}{c}0.030(3) \\
1 / 4 \\
0.326(4)\end{array}$ & $\begin{array}{c}0.0293(1) \\
1 / 4 \\
0.3261(1)\end{array}$ & $\begin{array}{ll}\beta_{11} & 0.0030(2) \\
\beta_{22} & 0.0144(15) \\
\beta_{33} & 0.0025(2) \\
\beta_{13} & 0.0006(1)\end{array}$ \\
\hline $\mathrm{Sb}_{\mathrm{II}}$ & $\begin{array}{l}x \\
y \\
z\end{array}$ & $\begin{array}{c}0.149 \\
3 / 4 \\
0.039\end{array}$ & $\begin{array}{c}0.149(4) \\
3 / 4 \\
0.036(4)\end{array}$ & $\begin{array}{c}0.1495(1) \\
3 / 4 \\
0.0360(1)\end{array}$ & $\begin{array}{ll}\beta_{11} & 0.0027(2) \\
\beta_{22} & 0.0230(15) \\
\beta_{33} & 0.0036(2) \\
\beta_{13} & 0.0013(1)\end{array}$ \\
\hline $\mathbf{S}_{\mathrm{I}}$ & $\begin{array}{l}x \\
y \\
z\end{array}$ & $\begin{array}{c}0.047 \\
1 / 4 \\
0.883\end{array}$ & $\begin{array}{c}0.055(15) \\
1 / 4 \\
0.880(15)\end{array}$ & $\begin{array}{c}0.0497(3) \\
1 / 4 \\
0.8769(3)\end{array}$ & $\begin{array}{ll}\beta_{11} & 0.0032(2) \\
\beta_{22} & 0.0180(25) \\
\beta_{33} & 0.0027(3) \\
\beta_{13} & 0.0004(3)\end{array}$ \\
\hline $\mathrm{S}_{\mathrm{II}}$ & $\begin{array}{l}x \\
y \\
z\end{array}$ & $\begin{array}{c}0.125 \\
3 / 4 \\
0.439 \\
\end{array}$ & $\begin{array}{l}0.131(14) \\
3 / 4 \\
0.441(14)\end{array}$ & $\begin{array}{c}0.1251(3) \\
3 / 4 \\
0.4386(3)\end{array}$ & $\begin{array}{ll}\beta_{11} & 0.0035(3) \\
\beta_{22} & 0.0177(25) \\
\beta_{33} & 0.0024(3) \\
\beta_{13} & 0.0008(3)\end{array}$ \\
\hline $\mathrm{S}_{\mathrm{III}}$ & $\begin{array}{l}x \\
y \\
z\end{array}$ & $\begin{array}{c}0.208 \\
1 / 4 \\
0.194\end{array}$ & $\begin{array}{c}0.214(14) \\
1 / 4 \\
0.189(13)\end{array}$ & $\begin{array}{c}0.2079(3) \\
1 / 4 \\
0.1917(3)\end{array}$ & $\begin{array}{ll}\beta_{11} & 0.0031(3) \\
\beta_{22} & 0.0267(26) \\
\beta_{33} & 0.0023(3) \\
\beta_{13} & 0.0002(3)\end{array}$ \\
\hline
\end{tabular}

shown by the interatomic distances of $S_{I}$ at $2.455 \AA$, two $S_{I I I}$ at $2.678 \AA$ and two $S_{I}$ at $2.854 \AA$, and also the bond angles given in Table 3. In addition another two $\mathrm{S}$ atoms (two $\mathrm{S}_{\text {II }}$ at $3.373 \AA$ ) lie near $\mathrm{Sb}_{\mathrm{II}}$. Both $\mathrm{Sb}_{\mathrm{I}}$ (three $\mathrm{S}$ bonded and four $\mathrm{S}$ nearby) and $\mathrm{Sb}$ II (five $\mathrm{S}$ bonded and two nearby) are surrounded by seven $\mathrm{S}$ atoms, which have a similar orientation as shown by their bond angles in Table 3. Both the trigonal pyramid (trivalent $\mathrm{Sb}_{\mathrm{I}}$ ) and square pyramid 
Table 3. Interatomic distances and bond angles of stibnite

\begin{tabular}{|c|c|c|c|c|c|c|c|c|c|}
\hline $\mathrm{Sb}_{\mathrm{I}}-\mathrm{S}_{\text {III }}$ & $2.521(3) \AA$ & \multicolumn{2}{|c|}{$\mathrm{S}_{\mathrm{II}}-\mathrm{Sb}_{\mathrm{I}}-\mathrm{S}_{\mathrm{III}}(2)$} & $87.49(8)^{\circ}$ & \multicolumn{2}{|c|}{$S_{I}-S_{b_{I I}}-S_{I I I}(2)$} & $88.08(8)^{\circ}$ & $\mathrm{Sb}_{\mathrm{II}}-\mathrm{S}_{\mathrm{I}}-\mathrm{Sb}_{\mathrm{II}}$ & $84.46(8)^{\circ}$ \\
\hline$-\mathrm{S}_{I I}(2)$ & $2.539(2)$ & $\mathrm{S}_{\mathrm{I}}-$ & $-\mathrm{S}_{\mathrm{III}}(2)$ & $77.95(8)$ & $\mathrm{S}_{\mathrm{I}}-$ & $-\mathrm{S}_{\mathrm{I}}(2)$ & $83.47(8)$ & $\mathrm{Sb}_{\mathrm{II}}-\quad-\mathrm{Sb}_{\mathrm{II}}(2)$ & $96.53(9)$ \\
\hline$-S_{I}(2)$ & $3.111(3)$ & $\mathbf{S}_{\mathbf{I}}-$ & $-\mathrm{S}_{\mathrm{I}}$ & $76.14(5)$ & $\mathrm{S}_{\mathrm{I}}-$ & $-S_{I}$ & $84.46(6)$ & & \\
\hline$-S_{I I}$ & $3.167(3)$ & $\mathbf{s}_{\mathrm{I}}-$ & $-\mathrm{S}_{\mathrm{II}}(2)$ & $91.22(7)$ & $\mathrm{S}_{\mathrm{I}}-$ & $-S_{I I I}(2)$ & $91.42(6)$ & $\mathrm{Sb}_{\mathrm{I}}-\mathrm{S}_{\mathrm{II}}-\mathrm{Sb}_{\mathrm{I}}(2)$ & $98.13(11)$ \\
\hline \multirow[t]{2}{*}{$-S_{I I I}$} & $3.642(3)$ & $\mathrm{S}_{11}-$ & $-\mathrm{S}_{\mathrm{II}}$ & $98.13(8)$ & $\mathrm{S}_{\mathrm{III}-}$ & $-\mathbf{S}_{I I I}$ & $91.50(7)$ & \multirow[b]{2}{*}{$\mathrm{Sb}_{\mathrm{I}}-\mathrm{S}_{\mathrm{III}}-\mathrm{Sb}_{\mathrm{II}}(2)$} & \\
\hline & & $S_{I I-}$ & $-\mathbf{S}_{I I}(2)$ & $79.65(8)$ & $\mathbf{S}_{\mathbf{I}}-$ & $-S_{\text {II }}(2)$ & $73.37(7)$ & & $101.14(8)$ \\
\hline $\mathrm{Sb}_{\mathrm{II}}-\mathrm{S}_{\mathrm{I}}$ & $2.455(3)$ & $\mathbf{S}_{\mathbf{I}}-$ & $-\mathrm{S}_{\mathrm{III}}(2)$ & $70.90(7)$ & $\mathrm{S}_{\mathrm{II}^{-\cdots}}$ & $-\mathrm{S}_{\text {III }}(2)$ & $67.54(8)$ & $\mathrm{Sb}_{11-}$ & $91.50(9)$ \\
\hline$-S_{I I I}(2)$ & $2.678(2)$ & $\mathbf{S}_{1 I}-$ & $-S_{I I I}$ & $59.69(7)$ & $\mathrm{S}_{\mathrm{II}^{--}}$ & $-\mathbf{S}_{\text {II }}$ & $69.31(4)$ & & \\
\hline$-\mathrm{S}_{\mathrm{I}}(2)$ & $2.854(2)$ & & & & & & & & \\
\hline$-\mathrm{S}_{\mathrm{II}}(2)$ & $3.373(2)$ & & & & & & & & \\
\hline
\end{tabular}


(quinvalent $\mathrm{Sb}_{\text {II }}$ ) are joined together with their basal planes parallel to the $b$ axis through common $\mathrm{S}$ atoms to form infinite chains.

Each trivalent $S_{I}$ at the vertex of a trigonal pyramid is bonded to three quinvalent $\mathrm{Sb}_{\mathrm{II}}\left(\mathrm{Sb}_{\mathrm{II}}\right.$ at $2.455 \AA$ and two $\mathrm{Sb}_{\mathrm{II}}$ at $2.854 \AA$ ), which occupy the corners of the basal plane. Two additional $\mathrm{Sb}_{\mathrm{I}}$ at $3.111 \AA$ also lie near $\mathrm{S}_{\mathrm{I}}$. Each divalent $\mathrm{S}_{\mathrm{II}}$ is bonded to two trivalent $\mathrm{Sb}_{\mathrm{I}}$ at $2.539 \AA$ with an angle of $98.13^{\circ}$. Three additional $\mathrm{Sb}$ atoms $\left(\mathrm{Sb}_{\mathrm{I}}\right.$ at $3.167 \AA$ and two $\mathrm{Sb}_{\mathrm{II}}$ at $3.373 \AA$ ) also lie near $\mathrm{S}_{\mathrm{II}}$. Each trivalent $\mathrm{S}_{\mathrm{III}}$ at

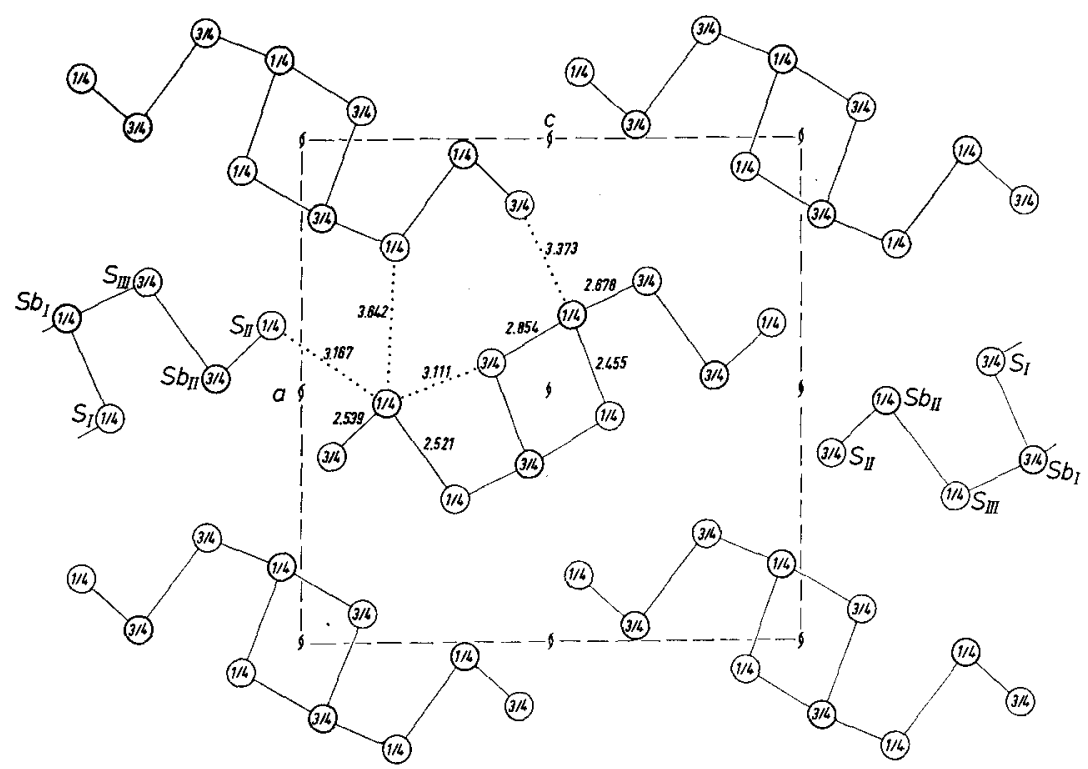

Fig. 1. Projection on $b$ axis to show atomic arrangement and interatomic distances in stibnite. Thick circles $-\mathrm{Sb}$ atom with heights $\frac{1}{4}$ and $\frac{3}{4}$, thin circles $-\mathrm{S}$ atom with heights $\frac{1}{4}$ and $\frac{3}{4}$

the vertex of a trigonal pyramid is bonded to three $\mathrm{Sb}$ atoms (trivalent $S b_{I}$ at $2.521 \AA$ and two quinvalent $S b_{I I}$ at $2.678 \AA$ ), which occupy the corners of the basal plane. An additional $\mathrm{Sb}_{\mathrm{I}}(3.642 \AA)$ also lies near SIII.

The physical properties of stibnite described by Dana (1941) such as (1) habitual long slender prismatic crystals, (2) perfect cleavage (100) and imperfect cleavages (001) and (101), (3) translational gliding parallel to (100) in the [010] direction, (4) flexibility about [001], and (5) hardness 2 may be related to its crystal structure. 


\section{Acknowledgements}

Dr.P. Engel, Dr. M. Ohmasa and Mr. A. Edenharter are thanked for their help. We are grateful to the International Business Machines, Extension Suisse, for the use of their IBM 360/65 system at Basel. Some financial assistance was provided by National Research Council of Canada Grant Number A 5106.

\section{References}

J. D. Dana and E. S. Dana (1941), The system of mineralogy, Vol. 1. J. Wiley and Sons, New York.

W. Hofmann (1933), Die Struktur der Minerale der Antimonitgruppe. Z. Kristallogr. 86, 225-245.

International tables for $x$-ray crystallography (1962), Vol. III. Kynoch Press, Birmingham.

S. Ś́́avnIČar (1960), The crystal structure of stibnite. A redetermination of atomic positions. Z. Kristallogr. 114, 85-97.

B. J. Wuensch and C. T. Prewitt (1965), Corrections for x-ray absorption by a crystal of arbitary shape. Z. Kristallogr. 122, 24-59. 